\title{
結晶模型を作ろう
}

\section{BB-dan Model}

\author{
安 達 洋 \\ 室蘭工業大学電気電子工学科 $巴 050-8585$ 北海道室蘭市水元町 27-1
}

(1998 年 5 月 29 日受理)

\section{Let's Make Crystal Models !!}

-BB-dan Model-

Hiroshi ADACHI

Department of Electrical and Electronic Engineering, Muroran Institute of Technology 27-1 Mizumoto-cho, Muroran, Hokkaido 050-8585

(Received May 29, 1998)

\begin{abstract}
BB-dan is Japanese brand name of ball bullets for toy guns. The bullets are plastic spheres with a diameter of $6 \mathrm{~mm}$, and are very cheap, for example 4,000 bullets costs you about 1,000 yen (equivalent to approximately 8 US dollars). Ball crystal models called some times "marble ball models" are constructed by using these tiny ball bullets. Here I give the name BB-dan model, because the bullet is called BB-dan. The constructing methods are detailed. The pictures of models for a hexagonal compact structure, a body centered cubic structure, a zinc-blende type structure and a $\mathrm{Si}(111)$ $7 \times 7$ reconstructed structure are given.
\end{abstract}

\section{1.はじめに}

\section{電界イオン顕微鏡や電界放射顕微鏡を用いて研究して} いる研究者の間では, 針状試料の先端の原子配列を理解 するのに球を並べて模型を作ることが古くから行われて いた。これを marble ball model と呼んでいる。日本語に 直訳すると大理石の球を並べた模型ということになる が，マーブルはどうもお菓子の名前に由来しているらし い。このモデルを作るには, 同じ半径の球が多数必要に なる。一辺に 10 個並べて立方体を作るとしたとき，単 純に考えて 1000 個も必要になるので, 簡単には作るこ とができなかった。日曜大工用品を扱っている店をのぞ いてみると,プラスチックの球が売られているが 1 つが 数十円もするので, 1000 個も買らと数万円にもなる。 数をそろえて注文すれば，もっと安く手に入るかもしれ ないが，それを扱ってくれる店を探すことも容易ではな

E-mail:adachi@muroran-it.ac.jp
い。特に筆者のように地方に住んでいるとなおさらであ る。

おもちゃ好きの学生が，おもちゃの銃に使用する弾丸 を買ってきた。值段が非常に安い。約 4,000 個入った袋 が 1,000 円程度で売られている。ディスカウントショッ プでは 700 円程度のところもあるとのことである。銃で 遊ぶ趣味を持っているのかと思い聞いてみたら，そのよ らな趣味はなく，これで結晶模型を作ろうと考えたとの ことであったので, 安心する一方で常に自分の課題を考 えながら余暇を楽しんでいることを知って，たのもしく も思った。私事で恐縮だが, 私の長男はこの弾を使う銃 で遊んでいて, 目を傷つけ半年ほど病院通いをさせられ た。危険なおもちゃなので, 売らないようにしてほしい と思う一方で，これほど安価に多数の球が売られている ことはありがたいことにも思える。この弾の商品名がビ ービー弾とのことなので, この結晶模型にビービーダン モデル（BB-dan model）と名付けてみた。

この弾は球状をしていて直径はおよそ $6 \mathrm{~mm}$ で扱いや 
すい大きさであるうえに，種々の色のものが売られてい るので, 結晶モデルを作るにはうってつけのものである。 ただし，直径が 1 つに限られるので，作ることができる ものが制限されるのは致し方ないことである。この球 10 個を一列に並べてノギスで長さを計ってみると $59.1 \mathrm{~mm}$ で，何度か計りなおしてもばらつきはほとんどない。お もちゃであるにもかかわらず，品質管理がしっかりして いるのに感心した。ロットによるばらつきがあるかも知 れないが，かなり正確に製造されていることをうかがい 知ることができた。

\section{2. 製}

作

プラスチックモデル用の接着剂を添付のブラシで少し ずつ塗布しながら球を並べていく。接着に要する時間は 非常に短く数十秒間押さえておくと，手を離しても移動 しない程度にまで接着する。完全に固着されるまでには 数時間放置する必要がある。簡単なジグ（作業工具）を 作っておくと，固着中にあえて手で押さえておく必要は ない。ただし，この接着剤は成分の大部分が溶剤で，フ ラスチックを溶かして，その溶けた部分同士を押しつけ ることによって接着するようになっている。したがって, 押しつける力が強いと溶ける部分が増えるので，球の中 心間の距離が小さくなってしまうことがある。押しつけ る力をほとんど加えないように注意しながら固着するの を待たないと，結晶が歪んでしまう結果になる。また， 固着直前には強い張力が働くので, 近くに接着剤を㙦布 した直後でまだ固着していない部分があると，その部分 を引き込んでしまうので,やはり結晶が歪む結果になる。 固着寸前には少しの補正なら可能なので，接着して十数 分後に歪みを確かめて, 補正するのが良い。この補正作 業には竹製の耳かきが非常に便利な道具となる。補正の 時期を失すると歪みが残ってしまうので, 後の結晶成長 が思うようにならなくなるので注意する必要がある。フ ラスチックを溶かさない型の接着剤があると便利だと思 うが，市販されているものでは，固着までの時間や付着 力などでそれぞれに一長一短があり，プラスチックモデ ル用の接着剂に勝るものはいまのところ見つけてはいな い。また，接着剂は球間の接触する部位のみにつけるよ うな注意をしないと結晶が歪む結果になる。

\section{3. 最ちょう密構造}

球の間を接着して作るので，原子を球にみたてたとき 原子間が接触している必要がある。最ちょう密構造の面 心立方格子と六方晶は原子球が接触しているので，単に 球を積み上げるだけで簡単に作ることができる。面心立 方格子の場合，\{001\} 面を基本におくより $\{111\}$ 面を

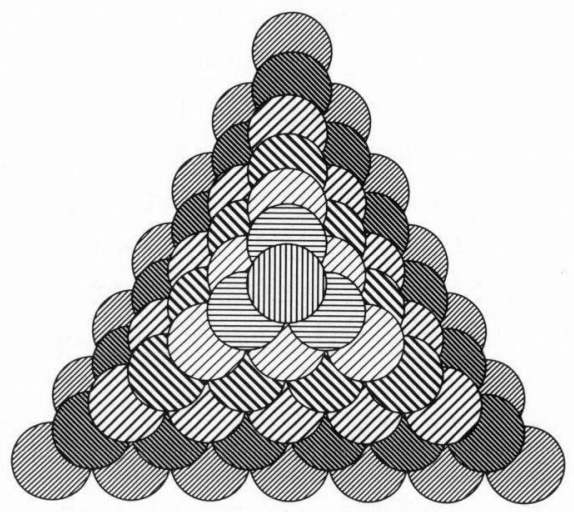

(a)

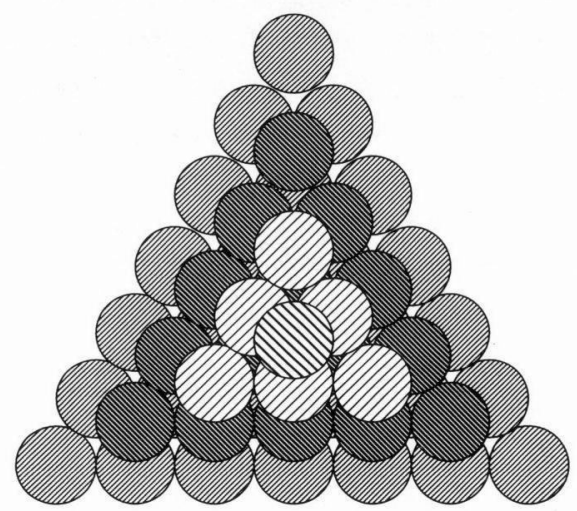

(b)

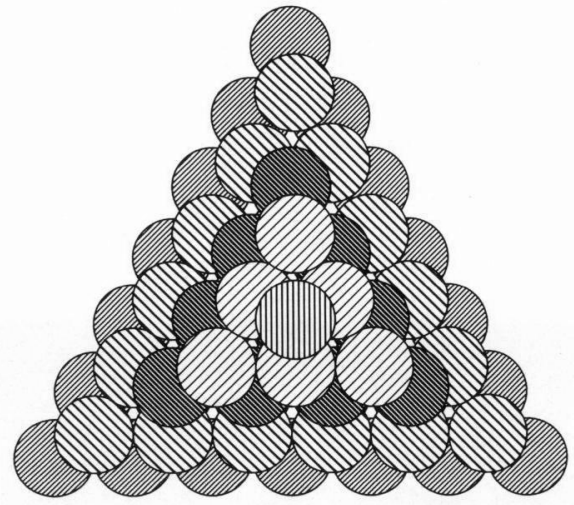

(c)

Fig. 1 Construction of the most compact packed structure. a) a tetrahedron of the face centered cubic structure (FCC). b) a corner-cube of FCC. c) a triangular cone of the hexagonal compact packed structure (HCP).

基本において構筑するほうが作りやすい。六方晶の場合 には，\{0001\} 面を基本におく。

平面上に球を互いに接触するように並べてゆくと, 球 は正三角形を基本格子にするように整然と並ぶ。第 1 層 
を並べて接着剤が乾くのを待って，第 2 層を接着しなが ら並べる。Fig. 1 に示したよ5に第 1 層を正三角形に並 ベ，第 2 層をそれより一回り小さな正三角形で終了し， 第 3 層はさらに一回り小さな正三角形で終了するように して積み上げてゆくと角錐状のものができ上がる。

Fig. 1 （a）に示すように単純に球を積み上げてゆくと 正四面体ができる。これは面心立方格子になっている。 正四面体のどの面を見ても正方形に球が並んでいるとこ ろがないので, なかなか面心立方格子に結びつけにくい。 Fig. 1 (b) のように球を並べるとやはり三角錐状になる が，今度は面上に正方状に球が並んでいるところが出て いるので, 立方格子になっていることが直感的に見て取 れる。角錐の面間の角度が直角になり面心立方格子にな ることが実感できる。実際に作って観察してみるとある 種の感激がある。とにかく作ってみることをお勧めする。

Fig. 1 の（a）と（b）の両方のものを作り, 両方の三 角形の面を接触させて合わせてみると, 球の並びが連続 的になっているのが見て取れる。Fig. 1 (a) の正四面体 が面心立方格子になっていることが納得でき，その稜が 面心立方格子の〈110〉軸になっているとも一目瞭然と なる。

第 3 層を並べるときには, 第 1 層との関係で 2 つの可 能性が出てくる。Fig. 1 (c) に示すように, 並べた面の 上方からみて第 1 層と第 3 層の球が同じ位置になるよう に並べると六方最ちょう密構造となる。第 1 層と第 3 層 の球が重ならない位置に並んでいる Fig. 1 の (a) や (b) では面心立方格子になる。第 3 層の原子の並べ方で，こ のように2つの結晶形が区別されることが体験できるう えに, 最近接原子間の並びが四角だったり, 三角だった りして, 教科書の図を見たり, コンピュータの画面を見 たりしているときには見落としている特徴が, 球を積み

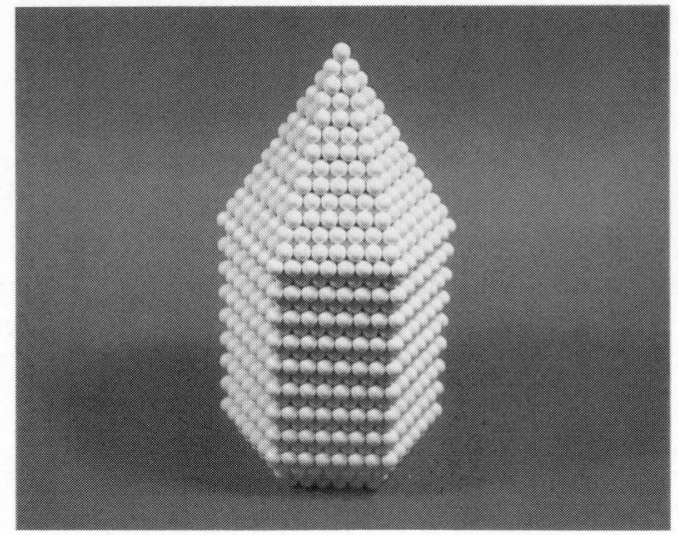

Fig. 2 An example of the hexagonal compact packed structure (HCP).
上げるという動作ではっきりと確認できるのもこの模型 を作ることの良い点と考える。

六方最ちょう密構造の場合, 底面が正六角形になるよ らにして, 同じように積み上げてみると, Fig. 2 に示し た写真のように水晶の結晶の頂部と似た形ができる。実 際の水晶と比較してみると頂角が鋭くなっているのに気 ゔく。水晶は, $\mathrm{SiO}_{2}$ 分子が規則的に並んでできる形で あり，その分子はとても球とは考えられない形をしてい るうえに, 結合手が立体的に出ているためで, このよう な差が現れてくる。

\section{4. 単純立方格子}

単純立方格子を作るには，直角を出すための簡単なジ グ (作業工具) が必要になる。箱の隅を利用するのも一 方法ではあるが, 私の場合は研究室の隅から約 $10 \mathrm{~cm}$ 角 で $1 \mathrm{~mm}$ 厚のアルミ板 1 枚と, 長さ約 $12 \mathrm{~cm}$ で $10 \mathrm{~mm}$ 角 $1 \mathrm{~mm}$ 厚のアルミアングルを 2 本を見つけて来て, Fig. 3 の写真に示すようにそれらをダブルクリップで固定し て使用している。アルミ材を利用したのは, 誤って接着 剂を落としてしまったとき, 結晶とジグが接着されるの を防ぐためである。アルミアングルは押し出し整形法で 作られるので, 非常に正確な直角に折り曲がっている。 一方の面をクリップで止めると, 必然的に他方の面は垂 直に立つことになる。この垂直面が，球を垂直に積み上 げるときに役に立つ。

2 本のアルミアングルをクリップでアルミ板に固定す るとき, その間の角度を分度器や三角定規を用いて正確 に 90 度に設定すれば，それに沿って球が並ぶので 90 度 を出すことができる。隣同士の球の色を変えると食塩の ようなイオン結晶も実現できる。\{111\} 面では正イオン 層と負イオン層が交互に重なっている様子も容易に理解 することができる。

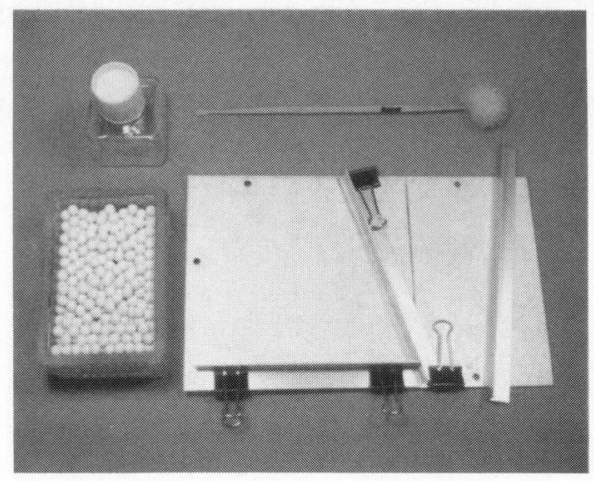

Fig. 3 Tools for making the crystal model. 


\section{5. 体心立方格子}

体心立方格子では，原子を球で置き換えたとき隣同士 間が接触する面は $\{110\}$ なので，この面に基本をおい て球を並べると容易に構成できる。基本格子の $\{110\}$

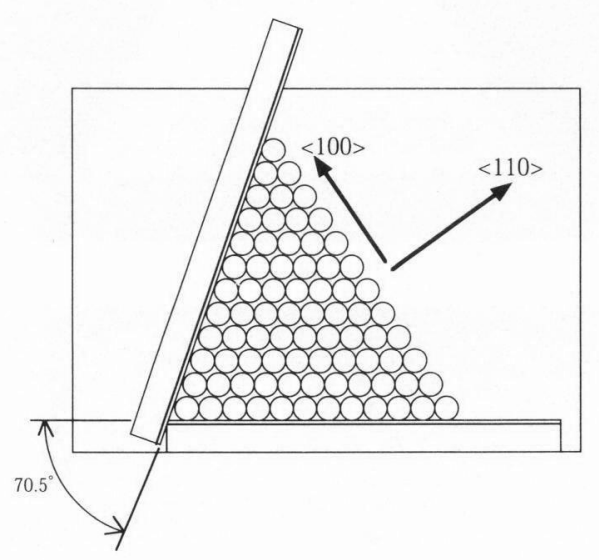

(a)

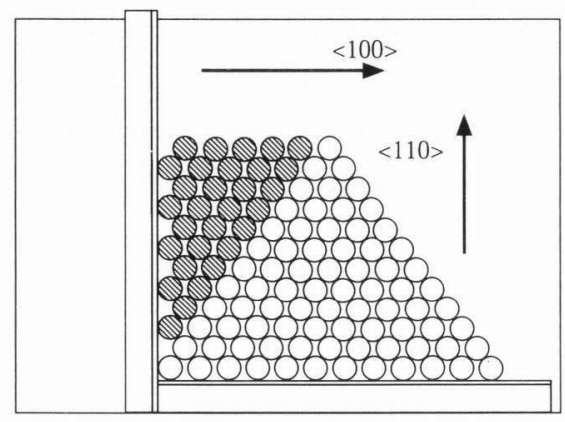

(b)

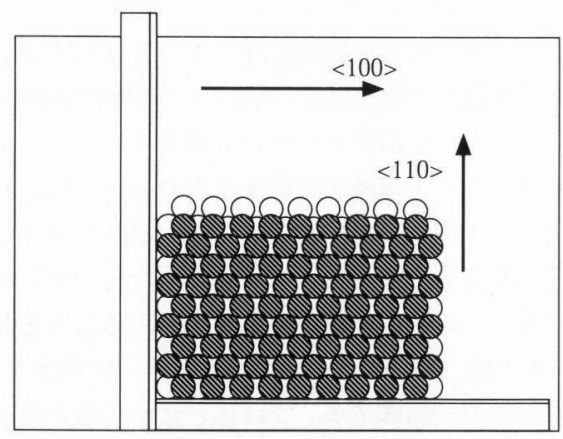

(c)

Fig. 4 Construction of (110) plane of the body centered cubic structure (BCC). a) The fundamental triangular structure. b) Extending to a rectangular structure. c) Stacking configuration over than two layers.
面は, 辺の長さの比が $1: \sqrt{2}$ の長方形なので, これに 沿って球を並べるには, Fig.4（a）に示すようにジグの 2 つのアングルの間の角度を, この長方形の辺と対角線 のなす角の 2 倍, つまり 70.5 度に設定してクリップで 止める。2つのアングルに挟まれたところに, 頂点から 順に球を並べていくと, 三角形状に $\{110\}$ 面の配置を 満足するように球が並び，基本形ができる。長方形の \{110\} 面が欲しいときには, Fig. 4 (b) に示すようにジ グの 2 本の間の角度を直角に調整し, この三角形の球の 並びの〈100〉軸を一方のアングルに接触するようにお いてさらに球を並べると作ることができる。この操作を するときに，接着剤が完全に固まってからジグをはずす ようにしないと変形してしまうので注意が肝要となる。

第 2 層を並べるには，(110）面が（110）面に直角に 交差することを考慮して, Fig. 4 (c) に示すように〈001〉 軸の並びをジグのアルミアングルの一方に接触させてお いて, 新しい球をアルミアングルの垂直面に接触し, か つ〈001〉軸の原子の間になるように並べて接着してい くと, アルミアングルに接触している面が（110）面と なる。第 3 層は, 今できた（110）を机などの平面上に おいて第 2 層の球の間に位置するように並べると構成で きる。各層ごとに〈110〉方向を一列ずつ小さくしてゆ くと，（110）面と（110）面に挟まれたところに（100） 面が形成される。このようにして（100）面ができるの で, 以後この面を基準に考えて球を積んでゆくと体心立 方格子が形成できる。Fig. 5 (a) は三角柱状に組んだ体

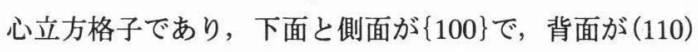
面，上面が (112) 面である。

体心立方格子を形成する金属では, 外力を加えると $\{110\}$ 面が滑り面となって塑性変形することが知られて いる。金属線を作るときの線引き工程は塑性変形で，そ のときの滑り面は $\{110\}$ 面であるから, 金属線の長さ 方向には〈110〉軸が並ぶことなる。球を並べて $\{110\}$ 面を作ってみるとこの面の凹凸が他の面に比べて著しく 小さく滑りやすいことが直感的に理解できる。

金属を電気化学的にエッチングして鋭い針状にして, 先端を観察するのに電界放射顕微鏡が良く用いられ，そ の標準的試料としてタングテン線がよく使われる。その とき, 放射パターンの中心に必ず $\{110\}$ 面がくるのは 線引き工程での塑性変形に原因があり, タングステンが 体心立方格子を形成していることから必然的にそうな る。Fig. 5 (b) は頂点が（110）面にくるように半球状 に組んだもので, タングステンの電界放射パターンの解 釈に使っているもので, 針先の様子が手に取るように解 る。 


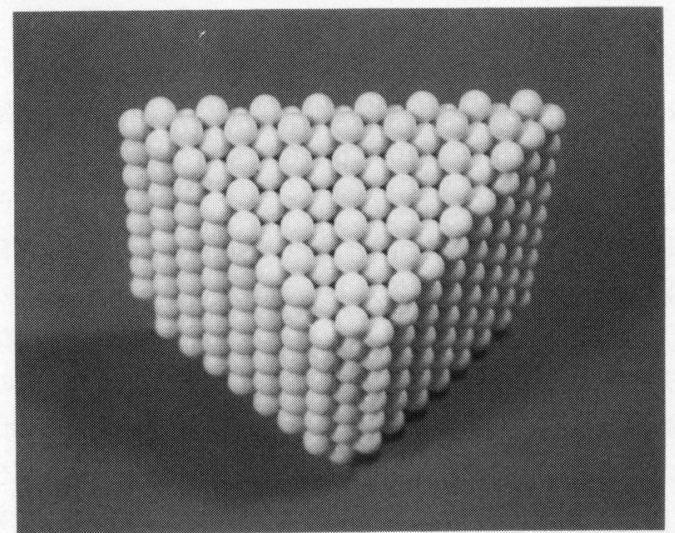

(a)

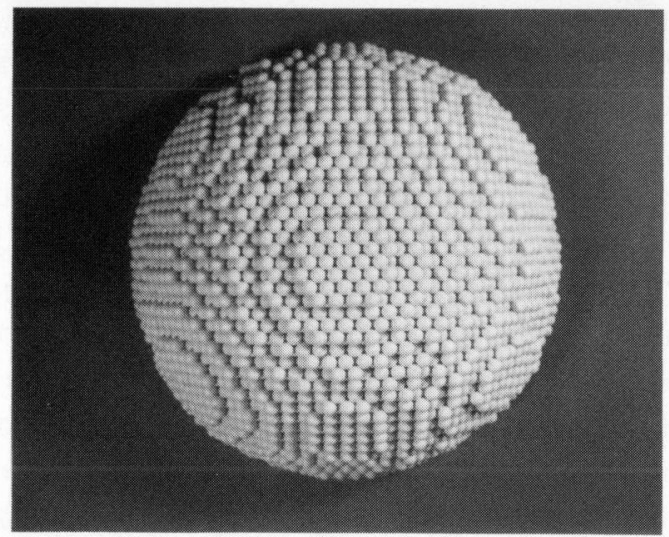

(b)

Fig. 5 Examples of the body centered cubic structure (BCC). a) A triangular bar. The top surface is (112), the sides and bottom surfaces are $\{100\}$, and the back surface is (110). b) A hemisphere of (BCC) directed to 〈110〉 axis.

\section{6. ダイヤモンド構造}

ダイヤモンド構造を作るには，一工夫が必要になる。 その理由は，どの方向の結晶面をみても原子に相当する 球を平面上で接触させて形成できる平面がないからであ る。今までの経験では, $\{111\}$ 面に基本をおいて構成す るのが最も簡単と思われる。体心立方格子の $\{111\}$ 面 の原子の並びがダイヤモンド構造の $\{111\}$ 面の並びと 同じになるので, この面のレプリカを作ってそれを基準 にして作る。Fig. 6 (a) の写真に示したものが, この目 的のために作った体心立方格子の $\{111\}$ 面である。こ の面に接着しない球を一面に並心゙る。この層は不用意に 接着剤を落としたときのためのバッファー層である。こ の上で球を接着剤で固定しながら一層つくり, 接着剂が 固化してから取り上げると，Fig. 6（b）に示したように

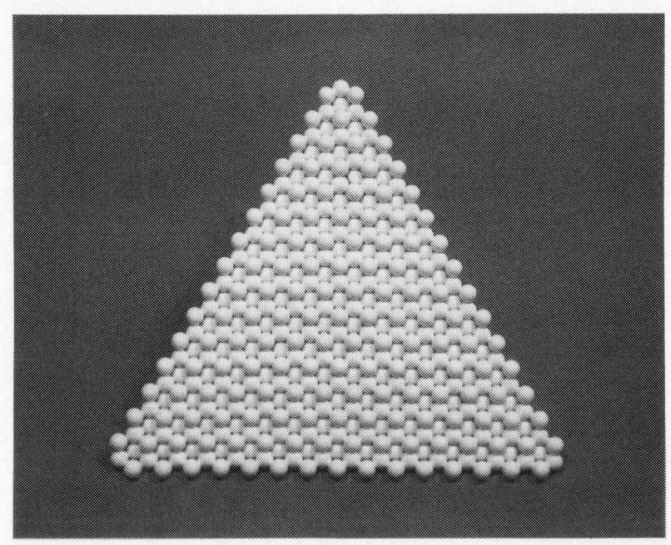

(a)

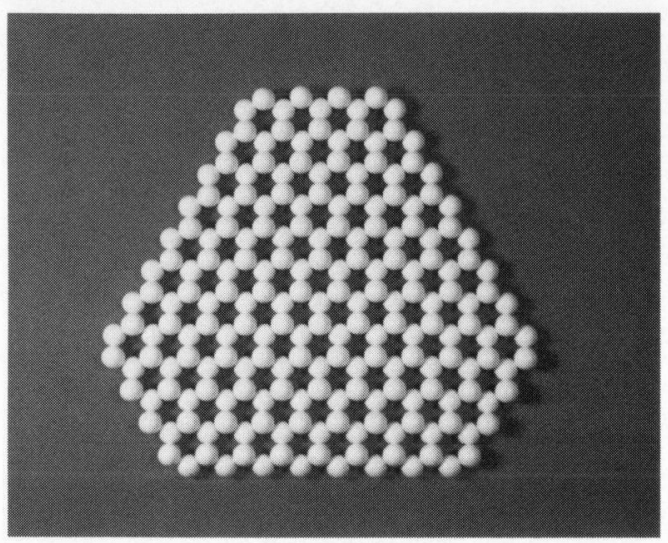

(b)

Fig. 6 Construction of the diamond structure. a) The die has a (111) surface of BCC. b) A layer structure of the diamond (111) surface made by a help of the die.

ダイヤモンド構造の〈111〉面の一層ができ上がってい る。同じものを必要の枚数作り, 重ねて接着するとダイ ヤモンド構造ができ上がる。しかし, 層間の接着の際に, 層間の原子の並びがダイヤモンド構造と一致するかの確 認が必要となる。単純にそのまま重ねると，体心立方格 子になるのは理の当然である。また, 層状のグラファイ 卜構造になることもある。まず, 小さなものをいくつか 作ってみて，その並びを一度確認してみることをお勧め する。その後, 目的の大きさのものを作ってみると良い。 これら 3 つの結晶構造が，これほどにまで似た原子配列 であることは，この模型を作ってみるまで，実感できな かった。

Fig. 7 は，このようにして作った閃覀鉛鉱型構造で, GaAs などの化合物半導体に見られる構造である。（111） 面が安定になるためには, その構成する一方の原子のみ 


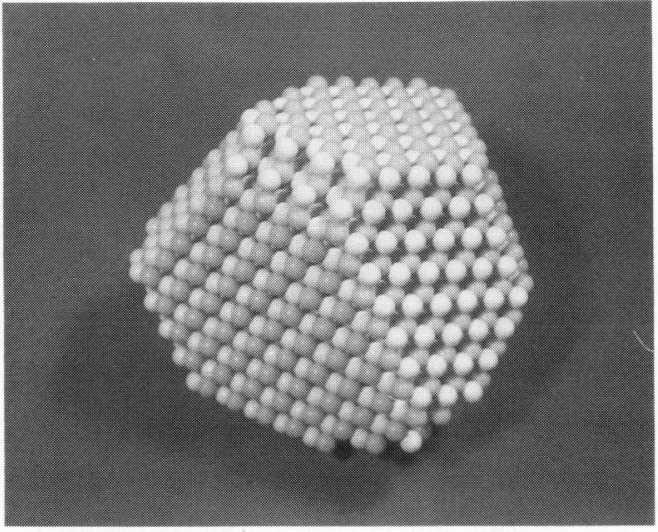

Fig. 7 An example of the zinc-blende structure.

が面に現れ，しばしば a 面や b 面，あるいは Ga 面や As 面といって区別される理由がはっきりと確認できる。

Fig. 8 は，Si（111）に現れる $(7 \times 7)$ 再構成面である。 STM で観察されるのは, 黒い球で表した吸着原子であ る。STM の画像では $\mathrm{Si}$ の $(7 \times 7)$ 構造の原子配列が観 察されるとされているが，画像の各々の輝点はこれほど 多くの原子の代表として現れてくる。このことが体感で きたのは, このモデルを作ってみて, 良いことだったと 考えている。また，ひし形に見える基本格子の半分ずつ の三角形で，原子の並びが基本の Si 結晶の並びと微妙 に違っていることもはっきりと観察できる。

球を並べるといら単純作業ではあるが，実際にやって みると研究室の日常とは異なった時間带が体験でき，落 ちついた時間を過ごすことができるうえに，球を並べて いると種々のことが頭の中を横切り, 日常を反省したり する時間帯が得られた。その意味では趣味の時間と同じ で, 非日常の時間が得られたと思っている。週末など時

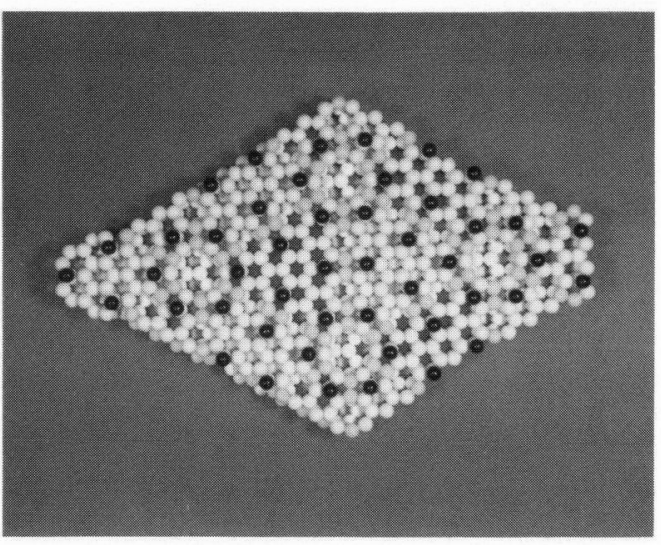

Fig. 8 An example of the $\mathrm{Si}(7 \times 7)$ reconstructed structure.

間の余裕があるときに作ると，単純作業であるがゆえに 時間を忘れて没頭することがあった。

プラスチックモデル用の接着剤の溶剤は, 無害とされ ているが，蒸気を換気するように気を配って頂きたい。 日曜大工用品を販売している店で, 活性炭入りのマスク を売っているので，それを利用することをお勧めする。 非常に効果があり，接着剤のにおいを感じないで作業が できた。とにかく，作ってみることをお勧めする。ここ には書けなかったいろいろとおむしろいことが見えてく ること請け合いです。

本稿は, 北海道大学, 山梨大学, 室蘭工業大学の三大 学が共同で開催しているジョイントセミナーでの原稿を もとにして書いた。投稿を勧めて下さいました山梨大学 の川村隆明先生に感謝します。また，図面や写真の製作 には室蘭工業大学の山根康一氏に負うところが大きい。 そのおかげで原稿を所定の締め切りに間に合わせること ができた。ここに感謝します。 